\title{
RESPON PEMBERIAN MOL (MIKRO ORGANISME LOKAL ) REBUNG BAMBU TERHADAP PERTUMBUHAN CABAI RAWIT (Capsicum frutescens L.) DI MEDIA GAMBUT
}

\author{
Yunus Radiarta, Hilwa Walida dan Novilda Elizabeth Mustamu \\ Program Studi Agroteknologi, Sekolah Tinggi Ilmu Pertanian Labuhabatu \\ J1. SM. Raja No. 126A Rantauprapat, Sumatera Utara \\ e-mail :vilda78@gmail.com
}

\begin{abstract}
The study aimed to determine the response of giving MOL (Micro Local Organisms) to the growth of cayenne pepper (Capsicum frutescensL.) On peat media. The research was carried out in the villages of Sempurna, Aek Tapa, Rantauprapat, North Sumatra at the beginning of April to July 2018. The materials used for conducting the research were cayenne seeds, peat soil, bamboo shoot MOL, polybags, water. The tools used for the research are hoes, machetes, ropes, meters, scissors, saws, knives, liters and writing instruments. This study used a Randomized Block Design (RBD) method with one factorial. This research was divided into 4 treatments which were repeated 10 times, namely: M0: Control, M1: Giving MOL as much as 1 liter / repeat, M2: Giving MOL as much as 1.5 liters / repetition, M3: Giving MOL as much as 2 liters / repetition. Micro Application of Local Organisms Bamboo shoots can increase the growth of cayenne. Giving Micro Bamboo 1 Local Organisms 1 liters gives a good response to the high growth of chili plants with the highest achievement of $1.98 \mathrm{~cm}$ difference. Giving Micro Bamboo Local Organisms 1 liters bamboo shoots gave a good response to the stem diameter of cayenne pepper with the highest achievement of the highest difference of $2.80 \mathrm{~mm}$. Giving Micro Local Organisms bamboo shoots 2 liters give a good response to the number of leaves of cayenne pepper with the achievement of the highest difference of 13 strands.
\end{abstract}

Keywords: bamboo shoots, Cayenne pepper, Local microorganisms, peat soil

\section{PENDAHULUAN}

\section{Latar Belakang}

Cabai rawit (Capsicum frutescens L.) merupakan sayur buah yang sangat digemari masyarakat di Indonesia. Cabai banyak mengandung minyak atsiri yang memberi rasa pedas dan panas. Rasa pedasnya disebabkan oleh kandungan capsaisin yang sangat tinggi. Buah cabai banyak mengandung vitamin A dan C (Safira, 2011).

Secara umum buah cabai rawit mengandung zat gizi antara lain lemak,

protein, karbohidrat, kalsium, fosfor, besi, vitaminA, B1, B2, C dan senyawa alkaloid seperti capsaicin,oleoresin, flavanoid dan minyak esensial (Rukmana, 2004). Capsaicin (8methyl-N-vanillyl-6nonenamide) merupakan komponen utama alkaloid lipofilik yang memberikan rasa pedas pada cabai. Ukuran pedas dari cabai tergantung pada kandungan capsaicin dan senyawa kapsaisinoid lain yang dikandungnya capsaicin mencapai $90 \%$ dari 
total kapsaisinoid yang terdapat dalam cabai (Yola, 2013). Tiap jenis cabai mempunyai tingkat kepedasan yang berbeda.Capsaicin merupakan salah satu metabolit sekunder pada tanaman cabai. Capsaicin terdapat pada plasenta buah, tempat melekatnya biji (Astawan \&Kasih, 2008).

Disamping sebagai konsumsi dalam negeri, cabai juga merupakan komoditi eksport yang tinggi nilainya (Wahyudi \& Topan, 2011). Permintaan cabai setiap tahun meningkat seiring dengan bertambahnya jumlah penduduk, dan restoran. Banyaknya permintaan membuat harga cabai pada awal 2011 melonjak tinggi di pasaran. Hal ini karena produksi cabai belum mencukupi permintaan pasar dan kecurangan para pedagang yang menimbun dan menaikkan harga pasaran cabai.

Produksi cabai rawit di Indonesia dalam lima tahun terakhir (2010-2014) menunjukkan peningkatan dengan pertumbuhan sekitar $8.36 \%$ (BPS, 2015). Peningkatan produksi cabai rawit berdasarkan data pada tahun 2010 sampai dengan tahun 2014 tetap tidak dapat memenuhi kebutuhan cabai rawit nasional sehingga impor cabai rawit terus dilakukan setiap tahunnya, hal ini dikarenakan belum tercapainya potensi terhadap produksi cabai rawit sebesar 10 sampai dengan 20 ton/ha (Ditjen Bina Produksi Hortikultura, 2015).

Tanah merupakan sumber daya alam yang mempunyai peranan penting dalam berbagai segi kehidupan manusia, hewan dan tanaman. Karakteristik unsur-unsur dalam tanah sangat berpengaruh terhadap karakteristik unsur-unsur dalam tanaman yang tumbuh di atasnya, sehingga kandungan unsur-unsur essensial dan non essensial yang kurang atau berlebihan dalam jaringan tanaman akan mencerminkan kandungan unsur-unsur dalam tanah.

Di Indonesia tanah gambut terdapat cukup luas dan tergolong jenis tanah kedua yang terluas setelah podsolik.Pengembangan lahan gambut sebagai lahan pertanian terdapat berbagai kendala baik fisik, kimia maupun biologis. Budidaya tanaman pada lahan gambut dihadapkan oleh kendala antara lain $\mathrm{pH}$ yang rendah dan kandungan hara yang rendah diantaranya unsur $\mathrm{N}, \mathrm{P}$ dan K. Menurut Subagyo et al.(1996), potensi pengembangan budidaya pada lahan gambut diperlukan beberapa strategi pemupukan yang benar.

Karakteristik kimia tanah gambut di Indonesia sangat beragam dan ditentukan oleh kandungan mineral, ketebalan, jenis tanaman penyusun gambut, jenis mineral pada substratum (di dasar gambut)dan tingkat dekomposisi gambut. Polak (1975) mengemukakan bahwa gambut yang ada di Sumatera dan Kalimantan umumnya didominasi oleh bahan kayu-kayuan. Oleh karena itu komposisi bahan organiknya sebagian besar adalah lignin yang umumnya melebihi $60 \%$ dari bahan kering, sedangkan kandungan komponen lainnya seperti selulosa, hemiselulosa, dan protein umumnya tidak melebihi $11 \%$.

Larutan MOL adalah larutan hasil fermentasi yang berbahan dasar dari berbagai sumber daya yang tersedia setempat. Larutan MOL mengandung unsur hara mikro dan makro dan juga mengandung bakteri yang berpotensi sebagai perombak bahan organik, perangsang pertumbuhandan sebagai agens pengendali hama dan penyakit tanaman, sehingga MOL dapat digunakan 
baik sebagai dekomposer, pupuk hayati dan sebagai pestisida organik terutama sebagai fungisida (Yeremia, 2016).

Dari uraian di atas jelas diterangkan bahwa mikroorganisme lokal dapat memberikan dampak positif bagi perkembangan tanaman dan juga dapat memperbaiki sifat biologis maupun kimiawis tanah yang berguna bagi tanaman. Oleh karena itu penulismelakukan penelitian yang berjudul "Respon Pemberian MOL (Mikro Organisme Lokal ) Rebung Bambu Terhadap Pertumbuhan Cabai Rawit (Capsicum frutescens L.) di Media Gambut".

\section{METODOLOGI PENELITIAN}

\section{Lokasi dan Waktu Penelitian}

Penelitian ini dilakukan di Kelurahan Sempurna, Aek Tapa, Rantauprapat, Sumatera Utara pada awal bulan April sampai dengan Juli 2018.

\section{Bahan dan Alat}

Bahan yang digunakan untuk pelaksanaan penelitian adalah benih cabai rawit, tanah gambut, MOL rebung, polybag, air. Adapun alat yang digunakan untuk pelaksanaan penelitian adalah cangkul, parang, tali rafiah, meteran, gunting, gergaji, pisau, alat ukur satuan liter dan alat tulis.

\section{Metode Penelitian}

Penelitian ini menggunakan metode Rancangan Acak Kelompok ( RAK) dengan satu faktor. Penelitian ini terbagi menjadi 4 perlakuan yang diulang sebanyak 10 kali yaitu :
M0 : Kontrol

M1 : Pemberian MOL sebanyak 1 liter/ulangan

M2 : Pemberian MOL sebanyak 1.5 liter /ulangan

M3 : Pemberian MOL sebanyak 2 liter/ulangan

\section{Metode Analisis}

Analisis data diolah secara deskriptif yaitu dinyatakan dengan rataan melalui Ms. Excel.

\section{HASIL DAN PEMBAHASAN}

\section{Tinggi Tanaman (cm)}

Bibit cabai yang dipindahkan ke polibag rata-rata tingginya adalah $\mathrm{Mo}=5.83$ $\mathrm{cm}, \mathrm{M} 1=5.52 \mathrm{~cm}, \mathrm{M} 2=5.57 \mathrm{~cm}, \mathrm{M} 3=$ $6.34 \mathrm{~cm}$. Berikut menunjukkan selisih rataan pertumbuhan tinggi tanaman cabai rawit (Tabel 1).

Tabel 1. Selisih rataan tinggi tanaman cabai rawit6 MST

\begin{tabular}{lc}
\hline \multicolumn{1}{c}{ Perlakuan } & Tinggi tanaman $(\mathrm{cm})$ \\
\hline M0 (Kontrol) & 1.70 \\
M1 (MOL 1 L) & 1.98 \\
M2 (1.5 L) & 1.34 \\
M3 (MOL 2 L) & 1.59 \\
\hline
\end{tabular}

Berdasarkan Tabel 1 diatas menunjukkan pertumbuhan tinggi rata-rata tanaman cabai rawit terbaik terdapat pada perlakuan M1, yakni selisih rataan mencapai $1.98 \mathrm{~cm}$ yang mana pengaplikasian MOL rebung bambu yang diberikan adalah $1 \mathrm{~L}$. Unsur $\mathrm{N}$ merupakan unsur yang berperan dalam pembentukan klorofil yang berperan dalam aktivitas fotosintesis pada daun. Menurut Saragih et al. (2013), tinggi 
tanaman dan bobot kering tanaman akan meningkat seiring dengan penambahan unsur N. Menurut Suwardi \& Roy (2009), pemberian $\mathrm{N}$ yang semakin tinggi berpengaruh terhadap tinggi tanaman. Pada penelitian ini rata-rata pencapaian tinggi tanaman tertinggi yaitu pada perlakuan M1, selisih tinggi rata-rata mencapai $1.98 \mathrm{~cm}$. Tanaman tertinggi terdapat pada tanaman M1 10, tinggi tanaman $9.2 \mathrm{~cm}$. Hasil tersebut menunjukkan bahwa tingkat pertumbuhan sangat kecil pada umur tanaman 6 minggu setelah tanam. Ini dikarenakan ketersedian unsur hara yang berperan pada penambahan tinggi di lahan gambut kandungan haranya rendah diantaranya unsur N, P dan K (Subagyo et al., 1996).

Senyawa N yang terkandung dalam bahan organik berperan dalam sintesa asam amino dan protein secara optimal, selanjutnya digunakan dalam proses pertumbuhan dan perkembangan tanaman, sedangkan tanaman yang mengalami kekurangan unsur hara $\mathrm{N}$ menyebabkan tanaman menjadi kerdil (Decoteau, 2000). Ini membenarkan bahwa rendahnya penambahan tinggi tanaman pada lahan gambut disebabkan unsur hara $\mathrm{N}$ yang rendah. Penelitian ini memperlihatkan bahwa pemberian M1 (pemberian MOL 1 L) terhadap penambahan tinggi tanaman cabai lebih tinggi dari perlakuan tanpa pemberian MOL M0 (kontrol). Artinya pemberian MOL dapat memberikan asupan unsur hara $\mathrm{N}$ yang kurang pada lahan gambut.

Menurut Maspray (2012), larutan rebung bambu memiliki $\mathrm{C}$ organik dan giberelin yang tinggi yang mampu merangsang pertumbuhan tanaman.
Giberelin memiliki fungsi utama yaitu mendorong perkembangan biji, pemanjangan batang dan pertumbuhan daun (Dewi, 2008).

\section{Diameter Batang (mm)}

Dalam penelitian ini peneliti menyelaraskan diameter batang keseluruhan pada saat pemindahan ke polibag yakni M0 $=2 \mathrm{~mm}, \mathrm{M} 1=2 \mathrm{~mm}, \mathrm{M} 2=2 \mathrm{~mm}, \mathrm{M} 3=2$ $\mathrm{mm}$. Berikut selisih rataan diameter batang pada 6 MST (Tabel 2).

Tabel 2. Selisih rataan diameter batang tanaman cabai rawit 6 MST

\begin{tabular}{lc}
\hline \multicolumn{1}{c}{ Perlakuan } & $\begin{array}{c}\text { Diameter batang } \\
(\mathrm{mm})\end{array}$ \\
\hline M0 (Kontrol) & 0.70 \\
M1 (MOL 1 L) & 0.80 \\
M2 (MOL 1.5 L) & 0.50 \\
M3 (MOL 2 L) & 0.40 \\
\hline
\end{tabular}

Tabel 2 diatas menunjukkan bahwa selisih rataan diameter batang terbesar terdapat pada perlakuan M1, hal ini menunjukkan bahwa pemberian MOL $1 \mathrm{~L}$ berespon baik pada pertumbuhan diameter batang cabai rawit. Diameter batang adalah salah satu parameter yang diamati untuk mengetahui respon pertumbuhan tanaman. Pada penelitian ini menunjukkan hasil bahwa rataan selisih diameter mencapai 0.80 mm dibandingkan dengan tanpa pemberian MOL. Hal ini menunjukkan pemberian MOL berpengaruh pada pertumbuhan dimeter tanaman cabai rawit.

Diameter batang semakin bertambah dipengaruhi oleh unsur hara kalium. Penelitian Silahooy (2008), tentang efek pupuk $\mathrm{KCl}$ dan SP-36 terhadap kalium tersedia, serapan kalium dan hasil kacang tanah (Arachis hypogaea L.) di Desa Halong 
Kecamatan Baguala, menunjukkan bahwa pentingnya kalium dalam penambahan diameter batang berhubungan dengan fungsi kalium untuk meningkatkan kadarsclerenchyma pada batang. Sclerenchyma mempunyai fungsi memberi penebalan dan kekuatan pada jaringan batang sehingga tanaman lebih kuat atau tidak mudah rebah, dengan penambahan pupuk organik padat maka unsur hara kalium bertambah dan terjadi penambahan sclerenchyma.Penambahan sclerenchyma menyebakan diameter batang juga bertambah besar.

Rahmianna \& Bel dalam Silahooy (2008) menjelaskan bahwa pertumbuhan tanaman berkolerasi dengan penambahan konsentrasi kalium pada daerah pembesaran. Bila tanaman kekurangan kalium pada daerah pembesaran dan perpanjangan sel terhambat, akan mempengaruhi pertumbuhan tanaman. Menurut Khaswarina (2001) pada waktu terjadi pembelahan, karbohidrat yang dihasilkan akan ditransfer ketitik tumbuh batang yang menyebabkan terjadinya pembesaran diameter batang.

\section{Jumlah Daun (helai)}

Pada pemindahan bibit cabai rawit ke polibag diperoleh data rata-rata pertama yakni $\mathrm{M} 0=60$ helai, $\mathrm{M} 1=61$ helai, $\mathrm{M} 2=$ 58 helai, $\mathrm{M} 3=57$ helai. Berikut menunjukkan selisih jumlah daun masingmasing perlakuan (Tabel 3).

Tabel 3. Selisih jumlah daun cabai rawit pada 6 MST Perlakuan Jumlah daun (helai)

\begin{tabular}{lc}
\hline M0 (Kontrol) & 11.00 \\
M1 (MOL 1 L) & 5.00 \\
M2 (MOL 1.5 L) & 5.00 \\
M3 (MOL 2 L) & 13.00 \\
\hline
\end{tabular}

Tabel 3 menunjukkan bahwa perlakuan M3 merupakan pertambahan helai daun terbanyak yakni selisih mencapai 13 helai, ini menunjukkan bahwa pemberian MOL $2 \mathrm{~L}$, memberikan pengaruh yang baik terhadap pertambahan jumlah daun tanaman cabai. Pada penelitian ini menunjukkan penambahan jumlah rataan daun yang memberikan pengaruh terbaik yaitu pada perlakuan M3 yang mencapai selisih 13 helai daun pada 6 MST, yaitu pemberian MOL 2 L. Dari hasil pengamatan dari perlakuan MO, M1, M2, M3 menunjukkan perbedaan jumlah yang tidak terlalu signifikan. Semakin banyak daun semakin tinggi fotosintesis yang terjadi. Menurut Gardner dalamWahida et al. (2011), daun berfungsi sebagai organ utama fotosintesispada tumbuhan, efektif dalam penyerapan cahaya dan cepat dalam pengambilan $\mathrm{CO} 2$. Novizan dalam Dongoran, (2009) menyatakan bahwa, nitrogen dibutuhkan untuk membentuk senyawa penting seperti klorofil, asam nukleat, dan enzim sedangkan unsur hara mikro berfungsi terutama dalam pembentukan daun dan klorofil pada daun. Apabila pembentukan daun tersebut terganggu maka proses fotosintesis akan terganggu juga dan pertumbuhan tanaman terganggu dan jika terjadi kekurangan nitrogen, tanaman akan tumbuh lambat dan kerdil. Mengingat gambut memiliki unsur hara $\mathrm{N}$ yang rendah, pemberian MOL rebung bambu tersebut memberikan pengaruh yang baik. 


\section{KESIMPULAN DAN SARAN}

\section{Kesimpulan}

1. Pengaplikasian Mikro Organisme Lokal rebung bambu dapat meningkatkan pertumbuhan tanaman cabai rawit

2. Pemberian Mikro Organisme Lokal rebung bambu $1 \mathrm{~L}$ memberikan respon yang baik terhadap pertumbuhan tinggi tanaman cabai rawit dengan pencapaian rataan selisih tertinggi $1.98 \mathrm{~cm}$.

3. Pemberian Mikro Organisme Lokal rebung bambu $1 \mathrm{~L}$ memberikan respon yang baik terhadap diameter batang tanaman cabai rawit dengan pencapaian rataan selisih tertinggi $2.80 \mathrm{~mm}$.

4. Pemberian Mikro Organisme Lokal rebung bambu $2 \mathrm{~L}$ memberikan respon yang baik terhadap jumlah daun tanaman cabai rawit dengan pencapaian jumlah selisih tertinggi 13 helai.

\section{Saran}

Berdasarkan hasil penelitian yang diperoleh dari penelitian ini, menyarankan penggunaan Mikro Organisme Lokal rebung bambu untuk meningkatkan pertumbuhan tanaman di media gambut karena dapat meningkatkan pertumbuhan tanaman.

\section{DAFTAR PUSTAKA}

Decoteau. 2000. Vegetatif Crop. The Pennsylvania State University. USA.

Dewi I. R. 2008. Peranan dan Fitohormon bagi Pertumbuhan Tanaman. UNPAD. Bandung.
Direktur Jendral Bina Produksi Hortikultura. 2015. Statistik Hortikultura Tahun 2014. Dirjen Hortikultura , Departemen Pertanian, Jakarta 125 hal.

Dongoran, D. 2009. Respons pertumbuhan dan produksi jagung manis (Zea mays saccharataSturt.) terhadap pemberian pupuk cair TNF dan pupuk kandang ayam. Skripsi. Universitas Sumatera Utara. Medan.

Khaswarina. W. 2001. Keragaman Bibit Kelapa Sawit terhadap Pemberian Berbagai Kombinasi Pupuk di Pembibitan Utama.Jurnal NaturIndonesia.Vol.3(2):138-150.

Maspary. 2010. Cara sederhana membuat hormon/zpt organic sendiri. http://www,gerbangpertanian.com/20 10/09/cara-sederhana-membuathormon-zpt. html. Diakses Pada Tanggal Juli 2018.

Polak. 1975. The Rawa Lakbok (South Priangan, Java). Investigation into the composition of an eutrophic topogenous Bog. Cont. Gen. Agr. Res. Sta. No 8. Bogor

Rukmana, R. 2004. Usaha Tani Cabai Rawit. Kanisius. Jakarta

Safira, E.U. 2011. Jurus Sukses Bertanam 20 Sayuran di Pekarangan Rumah. Klaten.53.

Saragih. D., H. Hermina., N. Nurmauli. 2013. Pengaruh Dosis dan Waktu Aplikasi Pupuk Urea dalam Meningkatkan Pertumbuhan dan Hasil Jagung Pioner 27.Jurnal Agrotek Tropika 1(1) : 50-54 
Silahooy Ch. 2008. Efek Pupuk KCl dan SP36 terhadap Kalium Tersedia, Serapan Kalium dan Hasil Kacang Tanah (Arachis hypogaea L.) Pada Tanah Brunizem.

Subagyo, Maas A. 1996. Pengelolaan lahan basah dan gambut yang berwawasan lingkungan. Seminar nasional perancangan pemangunan pertanian berwawasan lingkungan pada lahan gambut. 25-26 September 1996

Suwardi., Roy, E. 2009. Efisiensi Penggunaan Pupuk $N$ pada Jagung Komposit Menggunakan Bagan Warna Daun. Balai Penelitian Tanaman Serelia. 115 hlm.

Wahida N. R. S. dan Hemusye H.L. 2011. Aplikasi pupuk kandang pada tiga varietas sorgum. http://pasca.unhas.ac.id/jurnal/file/d2 d881d09802af860d274c7b731740d.p df. (juli 2018)

Wahyudi, M. Topan.2011. Panen Cabai di Pekarangan Rumah. Agromedia Pustaka. Jakarta

Yeremia, E. 2016. Pengaruh Konsentrasi Mikroorganisme Lokal (MOL) dari Rebung Bambu Terhadap Pertumbuhan Tanaman Sawi Caisim (Brassica juncea L.) hal : 2

Yola,R., Zulfarman., Refilda. 2013. Penentuan Kandungan Kapsaisin pada Berbagai Buah Cabai (Capsicum) dengan Metode Kromatografi Cair Kinerja Tinggi (KCKT).Kimia Unand. 2(2):115119. 